\title{
Analisis Tingkat Kebisingan, Beban Kerja dan Kelelahan Kerja Bagian Weaving di PT. Wonorejo Makmur Abadi Sebagai Dasar untuk Perbaikan Proses Produksi
}

\author{
Yusa Rizal Septio ${ }^{1)}$, Bambang Suhardi ${ }^{* 2)}$, Rahmaniyah Dwi Astuti' ${ }^{3)}$ dan Iksan Adiasa ${ }^{4)}$ \\ ${ }^{1,2,3)}$ Program Studi Teknik Industri, Fakultas Teknik, Universitas Sebelas Maret \\ Jl. Ir.Sutami 36A Surakarta 57126, Indonesia \\ ${ }^{4)}$ Program Studi Teknik Industri, Fakultas Teknik, Universitas Teknologi Sumbawa, \\ J1 Raya Olat Maras, Kabupaten Sumbawa, Nusa Tenggara Bar. 84371. Indonesia
}

DOI:10.20961/performa.19.1.40111

\begin{abstract}
Abstrak
PT. Wonorejo Makmur Abadi memiliki 5 stasiun kerja, dimana kebisingan yang paling tinggi terdapat pada stasiun kerja weaving. Pada stasiun kerja weaving menggunakan 96 mesin yang beroperasi selama 24 jam dan menghasilkan tingkat kebisingan yang melebihi $N A B$ sebesar 96,5 dB. Intesitas kebisingan yang melebihi $N A B$ adalah salah satu faktor yang menyebabkan gangguan kesehatan pada pekerja. Dampak dari kebisingan pada pekerjaan adalah kelelahan dan menambah beban kerja. Penelitian ini bertujuan untuk mengetahui pengaruh kebisingan terhadap beban kerja dan kelelahan kerja pada tenaga kerja bagian weaving di PT. Wonorejo Makmur Abadi. Subjek dalam penelitian ini sebanyak 42 orang, teknik pengambilan sampel menggunakan rumus slovin. Teknik pengumpulan data dalam penelitian ini yaitu dengan melakukan pengukuran langsung intensitas kebisingan di tempat kerja, pengukuran beban kerja dengan metode CVL, dan pengukuran kelelahan kerja dangan kuesioner IFRC. Hasil dari perhitungan beban kerja adalah 2 pekerja tidak mengalami kelelahan karena memiliki nilai CVL $<30 \%$ dan 40 pekerja mendapatkan klasifikasi perlu dilakukan perbaikan karena memiliki nilai CVL antara 30\% - 60\%, dan hasil dari pengukuran kelelahan kerja adalah 15 orang pekerja dengan klasifikasi kelelahan tinggi, 22 orang pekerja dengan klasifikasi kelelahan sedang dan 5 orang pekerja dengan klasifikasi kelelahan rendah. Usulan pengendalian kebisingan dilakukan menggunakan pendekatan Noise Hierarchy Controls. Pendekatan dilakukan dengan analisis eliminasi, substitusi, engineering controls, administrative controls dan penyediaan alat pelindung telinga, usulan untuk beban kerja adalah penyediaan kursi ergonomis untuk istirahat sisipan pekerja stasiun weaving, dan usulan untuk kelelahan kerja adalah menjadwalkan waktu istirahat sisipan untuk tenaga kerja dan menciptakan lingkungan kerja yang nyaman bagi tenaga kerja.
\end{abstract}

Kata kunci: Kebisingan, Beban Kerja, Kelelahan Kerja

\begin{abstract}
PT. Wonorejo Makmur Abadi has 5 work stations with the highest noise is found in the weaving work station. At the weaving work station, it uses 96 machines that operate for 24 hours and produces a noise level that exceeds the NAB of $96.5 d B$. The intensity of noise that exceeds the NAB is one of the factors that cause health problems in workers. The impact of noise on work is fatigue and increases workload. This study aims to determine the effect of noise on workload and work fatigue in the weaving section at PT. Wonorejo Makmur Abadi. Subjects in this study were 42 people with the sampling technique used Slovin formula. Data collection techniques in this study are by directly measuring noise intensity at work, measuring workload with the CVL method, and measuring work fatigue with the IFRC questionnaire. The results of the workload calculation are 2 workers do not experience fatigue because they have a CVL value $<30 \%$ and 40 workers get a classification needs to be improved because it has a CVL value between $30 \%-60 \%$, and the results of the measurement of work fatigue are 15 workers with fatigue classification high, 22 workers with moderate fatigue classification and 5 workers with low fatigue classification. The proposed noise control is carried out using the Noise Hierarchy Controls approach. The approach is carried out with the analysis of elimination, substitution, engineering controls, administrative controls and the provision of ear protection equipment, the proposal for workloads and work fatigue is the provision of an ergonomic chair for resting between working hours at the weaving station
\end{abstract}

Keyword: Noise, Workload, Fatigue at Work

\section{Pendahuluan}

Kelelahan dapat diartikan dengan sebuah keadaan yang berbeda dalam tubuh kita baik mental atau fisik dan berdampak pada menurunnya aktivitas pekerjaan dan melemahnya ketahanan fisik pada tubuh dalam bekerja (Suma'mur, 2009). Selain itu, kelelahan kerja juga dapat menurunkan prestasi ataupun motivasi operator dalam melakukan pekerjaan (Grandjean, 2010).

Beban kerja ialah konsep yang diperlukan untuk menjelaskan sejauh mana tenaga kerja telah menggunakan kerja mental dan fisiknya untuk tugas tertentu. Beban kerja dipengaruhi oleh tuntutan

*Corresponding author: bambangsuhardi@staff.uns.ac.id 
eksternal sebuah pekerjaan, lingkungan, faktor organisasi dan psikologis (Hoonaker, 2011). Beban kerja fisik menunjukkan seberapa banyak aktivitas fisik yang dilakukan manusia selama bekerja. (Hima, 2011). Untuk menghitung beban kerja fisik, salah satu metode yang dapat digunakan yaitu metode Cardiovascular Load (CVL), yang membandingkan peningkatan denyut nadi istirahat dengan denyut nadi kerja.

Menurut Arief (2013), kebisingan adalah suara yang tidak diinginkan yang merupakan arus energi yang berbentuk gelombang dan memiliki tekanan yang dapat berubah-ubah tergantung sumber dari kebisingan tersebut, sehingga sampai pada telinga dan merangsang pendengaran. Kebisingan akan menimbulkan gangguan terhadap pekerjaan yang sedang dilakukan seseorang melalui gangguan psikologi dan gangguan konsentrasi sehingga dapat menurunkan produktivitas pada pekerja (Sasongko, 2010).

Berdasarkan penelitian yang telah dilakukan Fitria (2012), intensitas kebisingan yang melebihi Nilai Ambang Batas (NAB) dapat menyebabkan kelelahan untuk para pekerja. Kebisingan dapat meningkatkan denyut nadi konstruksi pembuluh darah perifer, terutama pada tangan dan kaki, serta dapat menyebabkan pucat dan gangguan sensoris. Denyut nadi yang semakin cepat dapat mengindikasikan seseorang mengalami beban kerja fisik, mental, kelelahan dan stres. Jika hal ini tidak segera dikendalikan, maka akan mengakibatkan kecelakaan kerja yang dapat menurunkan produktivitas kerja dan menyebabkan kerugian materiil (Anizar, 2012). Pada tahun 2008, WHO (World Health Organization) melaporkan, diperkirakan hampir 14\% dari total tenaga kerja di negara industri terpapar bising melebihi $90 \mathrm{~dB}$. Beberapa penelitian sebelumnya pada proses produksi penelitian yang dilakukan oleh (Hidayah, 2011) menyatakan kebisingan lingkungan kerja departemen weaving berpengaruh pada kelelahan tenaga kerja. Penelitian lanjutan dilakukan oleh (Wahyuning, 2013) dan didapatkan hasil berupa tingginya kebisingan lingkungan kerja pada departemen weaving berdampak pada tingginya stress kerja operator. Selain stres kerja dan kelelahan tenaga kerja, kebisingan lingkungan kerja departemen weaving juga berdampak pada gangguan emosional dan beban kardiovaskular operator (Prabawati, 2016).

PT. Wonorejo Makmur Abadi (WMA) adalah salah satu perusahaan industri plastik yang memproduksi tikar plastik dengan berbagai merek dan ukuran. Perusahaan ini telah berdiri sejak tahun 1996 dan kini telah memiliki lebih dari 30 jenis tikar plastik dengan berbagai ukuran. Perusahaan tersebut melakukan proses produksi menggunakan beberapa mesin yaitu mesin mixer, mesin extruder, dan mesin weaving. Produksi PT. WMA terdiri dari 5 stasiun kerja, pada bagian produksi terdapat stasiun kerja weaving atau penganyaman yang dimana melakukan proses penganyaman stik-stik plastik menjadi tikar plastik sesuai dengan pola tertentu. Proses ini berlangsung selama 18 - 22 menit untuk tikar 2,5 m. Proses produksi pada stasiun weaving menggunakan mesin selama 24 jam yang sumber tenaganya adalah listrik.

Pekerjaan di bagian weaving memanfaatkan tenaga manusia dalam pengontrolan pada proses penganyaman. Jumlah pekerja pada stasiun weaving di PT. WMA berjumlah 24 orang setiap shift kerja, dimana 1 pekerja bertanggung jawab untuk mengoperasikan 4 mesin weaving. Operator yang bekerja pada stasiun weaving melakukan pekerjaan dengan keadaan berdiri dalam waktu 8 jam kerja. Hal ini menimbulkan kelelahan yang terjadi pada pekerja di stasiun weaving. Proses kerja tersebut menyebabkan tenaga kerja harus selalu dalam keadaan berkonsentrasi dan selalu siaga apabila sewaktu-waktu terjadi kesalahan pada saat proses penganyaman tikar. Proses kerja ini menyebabkan bertambahnya beban yang menyebabkan pekerja mudah untuk merasakan kelelahan kerja, sehingga menyebabkan produktivitas menurun. Agar produktivitas pekerja dapat meningkat atau lebih optimal, sistem K3 atau kesehatan dan keselamatan kerja perlu dijalankan secara tertib yaitu dengan cara mengevaluasi dan mengendalikan kelelahan kerja pada pekerja.

Survei pendahuluan telah dilakukan dengan melakukan penyebaran kuesioner mengenai keluhan subjektif pekerja yang dilakukan kepada 42 pekerja stasiun weaving yang bekerja pada shift kerja pagi di PT. WMA. Berdasarkan hasil tersebut, diperoleh bahwa $24 \%$ pekerja konsentrasinya sangat terganggu akibat kebisingan yang berlebih, 67\% pekerja konsentrasinya terganggu, dan 9\% pekerja konsentrasinya tidak terganggu akibat kebisingan yang berlebih. Apabila konsentrasi dari pekerja terganggu, maka akan mengakibatkan kesalahan pekerja dalam melakukan aktivitas yang akan menyebabkan kecelakaan kerja serta produktivitas menurun. Hal tersebut juga dibenarkan oleh manajer HRD PT. Wonorejo Makmur Abadi yang menyatakan bahwa sebagian besar pekerja mengalami gangguan konsentrasi akibat suara bising yang dihasilkan oleh mesin weaving pada stasiun kerja weaving.

Berdasarkan permasalahan tersebut, perlu adanya penelitian lebih lanjut untuk mengetahui tingkat kebisingan, beban kerja, dan kelalahan pekerja khususnya pekerja yang berada di stasiun kerja weaving PT. WMA. 


\section{Metode Penelitian}

Penelitian dilakukan pada bagian produksi PT. Wonorejo Makmur Abadi. Metode penelitian yang digunakan pada pengumpulan data dilakukan dengan kuesioner dan pengambilan data secara langsung. Pengambilan data kebisingan dilakukan secara langsung untuk mengetahui intensitas tingkat kebisingan. Kuesioner diberikan kepada pekerja untuk mengetahui apakah ada pengaruh kebisingan terhadap beban kerja dan kelalahan kerja. Dalam penelitian ini, pengambilan data kebisingan dilakukan menggunakan alat Envirometer untuk mengukur tingkat kebisingan stasiun kerja. Berdasarkan data tersebut, selanjutnya dilakukan perhitungan tingkat kebisingan ekuivalen. Setelah itu, dilakukan pengambilan data denyut nadi dengan menggunakan alat Mi Band 2 untuk dilakukan perhitungan beban kerja dengan menggunakan metode Cardiovascular Load (CVL). Kemudian dilakukan penyebaran kuesioner kepada 42 pekerja untuk mengukur kelelahan pekerja dengan menggunakan kuesioner Industrial Fatigue Research Committee (IFRC).

Setelah mendapatkan hasil dari pengukuran yang telah dilakukan kemudian dilakukan analisis penyebab terjadinya hasil pengukuran tersebut tinggi. Kemudian pada penelitian ini memberikan alternatif solusi dan analisisnya untuk masalah yang dihadapi pada studi kasus yang diteliti.

\section{Hasil dan Pembahasan}

\subsection{Perhitungan Kebisingan}

Berikut rekapitulasi hasil perhitungan Leq stasiun weaving yang kemudian akan digunakan untuk menghitung nilai Ls (waktu pengukuran selama siang hari) dan Lm (waktu pengukuran selama malam hari).

Tabel 1. Rekapiulasi Perhitungan Leq Stasiun Weaving

\begin{tabular}{cc}
\hline $\begin{array}{c}\text { Waktu Pengukuran } \\
(\mathrm{Jam})\end{array}$ & Leq $(\mathrm{dB})$ \\
\hline $06.00-09.00$ & 96.7 \\
$09.00-14.00$ & 97.9 \\
$14.00-17.00$ & 96.6 \\
$17.00-22.00$ & 97.4 \\
$22.00-24.00$ & 95.2 \\
$24.00-03.00$ & 94.6 \\
$03.00-06.00$ & 92.9 \\
\hline
\end{tabular}

$\mathrm{Ls}=10 . \log 1 / 16\left[\left(\mathrm{~T} 1 \times 10^{\wedge}(0.1 \mathrm{~L} 1)\right)+\ldots \ldots \ldots . .+\left(\mathrm{T} 4 \times 10^{\wedge}(0.1 \mathrm{~L} 4)\right)\right] \mathrm{dB}$

$=10 . \log 1 / 16\left[\left(3 \times 10^{\wedge}(0.1 \times 96.7)\right)+\left(5 \times 10^{\wedge}(0.1 \times 97,9)\right)+\left(3 \times 10^{\wedge}(0.1 \times 96.6)\right)\right.$ $+\left(5 \times 10^{\wedge}(0.1 \times 97.4)\right)$

$$
=97.3 \mathrm{~dB}
$$

$\mathrm{Lm}=10 . \log 1 / 8\left[\left(\mathrm{~T} 5 \times 10^{\wedge}(0.1 \mathrm{~L} 5)\right)+\ldots \ldots \ldots \ldots+\left(\mathrm{T} 7 \times 10^{\wedge}(0.1 \mathrm{~L} 7)\right)\right] \mathrm{dB}$

$=10 . \log 1 / 8\left[\left(2 \times 10^{\wedge}(0.1 \times 95.2)\right)+\left(3 \times 10^{\wedge}(0.1 \times 94.6)\right)+\left(3 \times 10^{\wedge}(0.1 \times 92.9)\right)\right.$

$=94.2 \mathrm{~dB}$

$\mathrm{Lsm}=10 . \log 1 / 24\left[\left(16 \times 10^{\wedge}(0.1 \mathrm{Ls})+8 \times 10^{\wedge}(0.1 \mathrm{Lm})\right)\right] \mathrm{dB}$

$=10 . \log 1 / 24\left[\left(16 \times 10^{\wedge}(0.1 \times 97.3)+8 \times 10^{\wedge}(0.1 \times 96.5)\right)\right] \mathrm{dB}$

$=96.5 \mathrm{~dB}$

\subsection{Perhitungan Kelelahan}

Berikut adalah hasil pengolahan data kelelahan kerja menggunakan IFRC terhadap 42 pekerja weaving di PT. WMA yang dapat dilihat pada tabel 2.

Tabel 2. Hasil Perhitungan Kelelahan Kerja

\begin{tabular}{clcccccc}
\hline No & Nama & $\begin{array}{c}\text { Total Skor } \\
\text { Individu }\end{array}$ & $\begin{array}{c}\text { Klasifikasi } \\
\text { Kelelahan }\end{array}$ & No & Nama & $\begin{array}{c}\text { Total Skor } \\
\text { Individu }\end{array}$ & $\begin{array}{c}\text { Klasifikasi } \\
\text { Kelelahan }\end{array}$ \\
\hline 1 & S1 & 80 & Tinggi & 22 & S22 & 76 & Tinggi \\
2 & S2 & 76 & Tinggi & 23 & S23 & 74 & Sedang \\
3 & S3 & 71 & Sedang & 24 & S24 & 61 & Sedang \\
4 & S3 & 85 & Tinggi & 25 & S25 & 65 & Sedang \\
5 & S5 & 68 & Sedang & 26 & S26 & 78 & Tinggi \\
6 & S6 & 76 & Tinggi & 27 & S27 & 58 & Rendah \\
\hline
\end{tabular}


Tabel 2. Hasil Perhitungan Kelelahan Kerja (lanjutan)

\begin{tabular}{clcccccc}
\hline No & Nama & $\begin{array}{c}\text { Total Skor } \\
\text { Individu }\end{array}$ & $\begin{array}{c}\text { Klasifikasi } \\
\text { Kelelahan }\end{array}$ & No & Nama & $\begin{array}{c}\text { Total Skor } \\
\text { Individu }\end{array}$ & $\begin{array}{c}\text { Klasifikasi } \\
\text { Kelelahan }\end{array}$ \\
\hline 7 & S7 & 69 & Sedang & 28 & S28 & 70 & Sedang \\
8 & S8 & 79 & Tinggi & 29 & S29 & 72 & Sedang \\
9 & S9 & 51 & Rendah & 30 & S30 & 58 & Rendah \\
10 & S10 & 66 & Sedang & 31 & S31 & 80 & Tinggi \\
11 & S11 & 76 & Tinggi & 32 & S32 & 74 & Sedang \\
12 & S12 & 73 & Sedang & 33 & S33 & 70 & Sedang \\
13 & S13 & 72 & Sedang & 34 & S34 & 71 & Sedang \\
14 & S14 & 72 & Sedang & 35 & S35 & 85 & Tinggi \\
15 & S15 & 84 & Tinggi & 36 & S36 & 59 & Rendah \\
16 & S16 & 65 & Sedang & 37 & S37 & 76 & Tinggi \\
17 & S17 & 76 & Tinggi & 38 & S38 & 80 & Tinggi \\
18 & S18 & 80 & Tinggi & 39 & S39 & 74 & Sedang \\
19 & S19 & 74 & Sedang & 40 & S40 & 70 & Rendah \\
20 & S20 & 70 & Sedang & 41 & S41 & 72 & Sedang \\
21 & S21 & 72 & Sedang & 42 & S41 & 73 & Sedang \\
\hline
\end{tabular}

\subsection{Perhitungan Kelelahan}

Berikut adalah hasil pengolahan data beban kerja menggunakan CVL terhadap 42 pekerja weaving di PT. WMA yang dapat dilihat pada tabel 3.

Tabel 3. Hasil Pengolahan CVL

\begin{tabular}{ccccccc}
\hline Nama & Umur & $\begin{array}{c}\text { Denyut Nadi Istirahat } \\
\text { (menit) }\end{array}$ & $\begin{array}{c}\text { Denyut Nadi Kerja } \\
\text { (menit) }\end{array}$ & $\begin{array}{c}\text { Denyut Nadi Kerja } \\
\text { Maksimal }\end{array}$ & $\begin{array}{c}\text { Nadi } \\
\text { Kerja }\end{array}$ & CVL (\%) \\
\hline S1 & 35 & 62 & 105 & 165 & 43 & 41.75 \\
S2 & 26 & 69 & 110 & 174 & 41 & 39.05 .00 \\
S3 & 39 & 65 & 100 & 161 & 35 & 36.46 .00 \\
S4 & 36 & 75 & 115 & 164 & 40 & 44.94 \\
S5 & 40 & 68 & 100 & 160 & 32 & 34.78 \\
S6 & 40 & 65 & 101 & 160 & 36 & 37.89 \\
S7 & 37 & 67 & 101 & 163 & 34 & 35.42 .00 \\
S8 & 34 & 70 & 110 & 166 & 40 & 41.67 \\
S9 & 19 & 70 & 100 & 181 & 30 & 27.03 .00 \\
S10 & 32 & 71 & 104 & 168 & 33 & 34.02 .00 \\
S11 & 36 & 75 & 109 & 164 & 34 & 38.20 .00 \\
S12 & 33 & 71 & 111 & 167 & 35 & 36.46 .00 \\
S13 & 20 & 70 & 100 & 180 & 41 & 37.27 .00 \\
S14 & 41 & 69 & 108 & 159 & 31 & 34.44 .00 \\
S15 & 37 & 65 & 105 & 163 & 43 & 43.88 \\
S16 & 37 & 75 & 110 & 163 & 30 & 34.09 .00 \\
S17 & 27 & 67 & 112 & 173 & 43 & 40.57 .00 \\
S18 & 23 & 66 & 105 & 177 & 46 & 41.44 .00 \\
S19 & 45 & 75 & 108 & 155 & 30 & 37.50 .00 \\
S20 & 28 & 73 & 104 & 172 & 35 & 35.35 .00 \\
S21 & 34 & 68 & 105 & 166 & 36 & 36.73 \\
S22 & 43 & 70 & 112 & 157 & 35 & 40.23 .00 \\
S23 & 23 & 72 & 103 & 177 & 40 & 38.10 .00 \\
S24 & 30 & 68 & 103 & 170 & 35 & 34.31 .00 \\
S25 & 32 & 70 & 100 & 168 & 33 & 33.67 \\
S26 & 30 & 66 & 72 & 171 & 28 & 28.28 .00 \\
S27 & 29 & & & & & 42 \\
\hline
\end{tabular}


Tabel 3. Hasil Pengolahan CVL (lanjutan)

\begin{tabular}{ccccccc}
\hline Nama & Umur & $\begin{array}{c}\text { Denyut Nadi Istirahat } \\
\text { (menit) }\end{array}$ & $\begin{array}{c}\text { Denyut Nadi Kerja } \\
\text { (menit) }\end{array}$ & $\begin{array}{c}\text { Denyut Nadi Kerja } \\
\text { Maksimal }\end{array}$ & $\begin{array}{c}\text { Nadi } \\
\text { Kerja }\end{array}$ & CVL (\%) \\
\hline S28 & 24 & 70 & 108 & 176 & 38 & 35.85 \\
S29 & 35 & 70 & 105 & 165 & 35 & 36.84 \\
S30 & 25 & 74 & 108 & 175 & 34 & 33.66 \\
S31 & 25 & 69 & 113 & 175 & 44 & 41.51 .00 \\
S32 & 26 & 70 & 108 & 174 & 38 & 36.54 .00 \\
S33 & 36 & 69 & 102 & 164 & 33 & 34.74 \\
S34 & 40 & 71 & 102 & 160 & 31 & 34.83 \\
S35 & 29 & 72 & 115 & 171 & 43 & 43.43 .00 \\
S36 & 37 & 71 & 103 & 163 & 32 & 34.78 \\
S37 & 34 & 70 & 109 & 166 & 39 & 40.63 \\
S38 & 22 & 69 & 113 & 178 & 44 & 40.37 .00 \\
S39 & 26 & 70 & 109 & 174 & 39 & 37.50 .00 \\
S40 & 29 & 68 & 104 & 171 & 36 & 34.95 \\
S41 & 38 & 72 & 105 & 162 & 33 & 36.67 \\
S42 & 41 & 72 & 112 & 159 & 40 & 45.98 \\
\hline
\end{tabular}

\subsection{Usulan Pengendalian Kebisingan}

Dalam Hierarchy control terdapat 5 tahapan yang dilakukan untuk mengurangi resiko terpaparnya kebisingan yang ada di perusahaan yaitu eliminasi, subtitusi, engineering control, administrative control, dan penyediaan alat pelindung telinga.

Pada tahap eliminasi tidak dapat dilakukan karena mesin weaving (tenun) adalah mesin utama dalam proses penenunan. Maka dengan ini tidak mungkin untuk dilakukannya eliminasi proses maupun sumber suara pada proses penenunan, maka tingkatan pengendalian kebisingan pada tahap eliminasi tidak layak dan dilanjutkan pada tahapan substitusi.

Setelah dilakukan perhitungan untuk tahap subtitusi mesin, kemampuan finansial perusahaan untuk melakukan pengendalian kebisingan tidak mampu memenuhi total biaya usulan pembelian 96 mesin baru. Berdasarkan hal tersebut, maka usulan pengendalian substitusi mesin tidak layak untuk direalisasikan.

Pada tahap engineering control, upaya penambahan barrier dan enclosure tidak dapat dilakukan karena dapat membatasi pekerja dengan mesin. Pekerjaan tenun adalah pekerjaan yang dilakukan dengan adanya interaksi secara langsung antara pekerja dengan mesin. Pada PT. Wonorejo Makmur Abadi mesin tenun yang digunakan adalah mesin tenun tipe manual yang tidak dapat ditinggal selama selang waktu tertentu. Hal tersebut memaksa pekerja selalu berada dekat pada mesin. Sehingga tahap selanjutnya adalah tahap pengendalian administratif.

Pada tahap pengendalian administratif, upaya yang dilakukan adalah penjadwalan rotasi pekerja, pada PT. Wonorejo Makmur Abadi penjadwalan rotasi kerja tidak dapat dilakukan khususnya pada bagian weaving, karena diperlukan keahlian khusus pada bagian tersebut. Pekerja bagian weaving memiliki keahlian yang didapatkan dari pelatihan yang dilakukan selama dua sampai tiga bulan sebelum menjadi pekerja tetap, sehingga pekerjaan tersebut tidak dapat digantikan oleh pekerja pada stasiun kerja yang lain. Apabila rotasi pekerja tetap dilakukan, maka belum tentu pekerja tersebut dapat melakukan pekerjaan di bagian weaving sehingga dapat menurunkan produktivitas dikarenakan perlu melakukan pelatihan ulang terhadap pekerja yang baru.

Usulan pengendalian kebisingan pada PT. Wonorejo Makmur Abadi meliputi penyediaan alat pelindung telinga yang sesuai nilai kebisingan lingkungan kerja diatas nilai ambang batas. Estimasi biaya yang dikeluarkan perusahaan untuk melakukan pengendalian kebisingan dapat dilihat pada Tabel 4.

Tabel 4. Estimasi Biaya Pembelian Alat Pelindung Telinga

\begin{tabular}{cccccc}
\hline No & Jenis & Merek & Harga & Jumlah & Total \\
\hline 1 & Earmuff & Luxury Headband & Rp 168,000.00 & 24 & Rp 4,032,000.00 \\
\hline
\end{tabular}


Perencanaan estimasi biaya yang dikeluarkan perusahaan adalah sebesar Rp 4.032.000. Berdasarkan estimasi harga pembelian alat pelindung telinga, pembelian alat pelindung telinga layak dilakukan karena masih berada pada batas kemampuan perusahaan.

\subsection{Usulan Pengendalian Beban Kerja dan Kelelahan Kerja}

Pekerjaan di bagian weaving PT. Wonorejo Makmur Abadi, mengharuskan pekerja untuk bekerja dalam posisi berdiri selama 7 jam. Hal ini dapat menyebabkan presentase hasil pengukuran CVL tinggi dan mempercepat terjadinya kelelahan pekerja, sehingga perlu dilakukan usulan penambahan kursi yang bertujuan untuk mengurangi beban kerja dan kelelahan yang dialami pekerja. Menurut Anggrianti (2017), posisi kerja berdiri dalam waktu lama akan membuat pekerja selalu menyeimbangkan tubuhnya sehingga menyebabkan beban kerja tambahan pada otot punggung dan otot kaki. Melakukan perubahan posisi tubuh antara duduk dan berdiri dapat mengurangi beban kerja (OSHD, 2016).

Pada penelitian ini diusulkan pemberian kursi untuk mengurangi beban kerja dan kelelahan pekerja stasiun weaving PT. Wonorejo Makmur Abadi. Perancangan desain kursi menggunakan data antropometri, dimana dimensi yang digunakan adalah panjang popliteal, tinggi popliteal, dan lebar pinggul. Setelah mendapatkan data antropometri kemudian dilakukan pengujian normalitas data, uji keseragaman data, dan uji kecukupan data.

Setelah itu, dilakukan perhitungan persentil untuk menentukan ukuran dimensi kursi dengan hasil sebagai berikut:

Tabel 5. Dimensi Kursi

\begin{tabular}{|l|c|c|l|}
\hline \multicolumn{1}{|c|}{ Dimensi } & Persentil & Ukuran & \multicolumn{1}{c|}{ Keterangan } \\
\hline $\begin{array}{l}\text { Panjang alas } \\
\text { kursi }\end{array}$ & 50 & $\begin{array}{c}44,36 \\
\mathrm{~cm}\end{array}$ & $\begin{array}{l}\text { Panjang alas kursi yang terlalu pendek menyebabkan tekanan pada } \\
\text { paha bagian tengah (Panero, 1980). Pengguna dengan persentil 5 dan } \\
\text { persentil 95 dapat lebih nyaman dalam menggunakan kursi tersebut. }\end{array}$ \\
\hline Tinggi kursi & 95 & $\begin{array}{c}46,75 \\
\mathrm{~cm}\end{array}$ & $\begin{array}{l}\text { Tinggi kursi pada persentil 95 sesuai dengan kebutuhan pekerja pada } \\
\text { posisi duduk saat istirahat. }\end{array}$ \\
\hline Lebar kursi & 95 & $\begin{array}{c}38,81 \\
\mathrm{~cm}\end{array}$ & $\begin{array}{l}\text { Lebar sebesar 38,81 cm agar dapat mendistribusikan tekanan dari } \\
\text { pantat sehingga pengguna dapat lebih nyaman dalam menggunakan } \\
\text { kursi. Lebar kursi tersebut juga akan cukup bagi pengguna dengan } \\
\text { ukuran persentil 5, dan persentil 50. }\end{array}$ \\
\hline
\end{tabular}

Berikut ini adalah perancangan desain kursi usulan yang ergonomis untuk digunakan oleh pekerja berdasarkan perhitungan yang telah dilakukan.

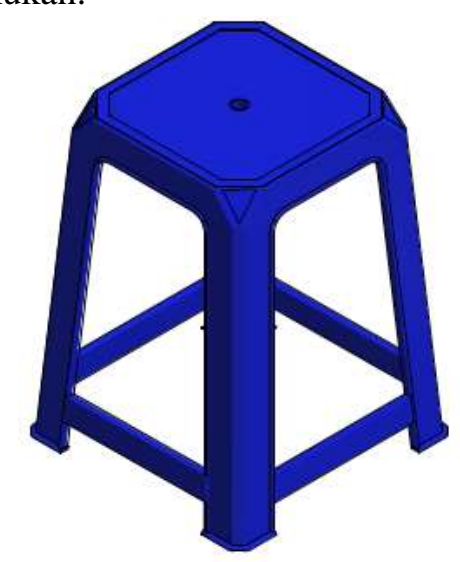

\section{Gambar 5.1 Desain Kursi Usulan}

Penggunaan kursi yang diusulkan dapat digunakan oleh pekerja pada saat istirahat di sela-sela jam bekerja. Hal ini dilakukan untuk mengurangi beban kerja dan kelelahan kerja yang dirasakan oleh pekerja pada stasiun weaving PT. Wonorejo Makmur Abadi.

\section{Simpulan}

Intensitas tingkat kebisingan pada PT. Wonorejo Makmur Abadi pada stasiun weaving memiliki nilai diatas ambang batas (NAB) yaitu 96,5 dB sedangkan pada stasiun lain tidak melebihi NAB. Usulan 
perbaikan pengendalian kebisingan yang diharapkan dapat diterapkan di PT. Wonorejo Makmur Abadi adalah dengan menyediakan alat pelindung telinga berupa earmuff dengan total estimasi biaya usulan sebesar Rp 4.032.000,00.

Hasil dari perhitungan CVL 2 pekerja tidak mengalami kelelahan karena memiliki nilai CVL $<30 \%$ dan 40 pekerja mendapatkan klasifikasi perlu dilakukan perbaikan karena memiliki nilai CVL antara 30\% - 60\%. Usulan perbaikan untuk beban kerja adalah dengan penambahan kursi ergonomis yang dapat digunakan oleh pekerja pada saat istirahat di sela-sela jam bekerja.

Hasil perhitungan tingkat kelelahan menggunakan IFRC didapatkan 42 orang pekerja pada stasiun weaving dimana semua pekerja berjenis kelamin perempuan didapatkan hasil 15 orang pekerja dengan klasifikasi kelelahan tinggi, 22 orang pekerja dengan klasifikasi kelelahan sedang dan 5 orang pekerja dengan klasifikasi kelelahan rendah.

\section{Daftar Pustaka}

Amir, Johan. (2019). Hubungan Kebisingan, Kelelahan Kerja dan Beban Kerja Mental Terhadap Stres Kerja Pada Pekerja Bagian Body Rangka PT.X. JURNAL KESEHATAN MASYARAKAT (e-Journal)

Volume 7, Nomor 1, Januari 2019 (ISSN: 2356-3346).

Anizar. (2012). Teknik Keselamatan dan Kesehatan Kerja di Industri. Yogyakarta : Graha Ilmu

Arief, L. (2013). Hearing Loss Prevention Program (HLPP). Jakarta: Modul Kuliah Universitas Esa Unggul Fakultas Ilmu Kesehatan Jurusan Kesehatan Masyarakat Peminatan Keselamatan dan kesehatan Kerja. Budiyanto T. (2010). Hubungan Kebisingan dan Massa Kerja Tehadap Terjadinya Stres Kerja Pada Pekerja Di Bagian Tenun "Agung Saputra Tex" Pinyungan Bantul Yogyakarta. KES MAS ISSN : 1978-0575.

Gaafar, M.I. (2004). Noise Pollution In Textile Industry (Case of Khartoum Spinning and Weaving Factory)

(Master Dissertation, University of Khartoum). Tersedia di Khartoum Dissertation Databese.

Hidayah. (2011). Pengaruh Kebisingan Terhadap Kelelahan Tenaga Kerja di Bagian Mesin Tenun PT. Iskandar Indah Printing Textile. Universitas Sebelas Maret : Surakarta.

Hima, Amalia dan Umami, Mahrus. (2011). Evaluasi Beban Kerja Operator Mesin pada Departemen Log and Veeneer Preparation di PT. XYZ. Jurnal Teknik dan Manajemen Idustri. Madura : Universitas Trunojoyo Madura.

Hoonaker, P. (2011). Measuring workload of ICU nurses with questionnaire survey: the NASA Task load Index (TLX). USA: IIE Transactions on Healthcare System Engineering.

K. Reinhold. 2014. Exposure to high or low frequency noise at workplaces: differences between assessment, health complaints and implementation of adequate personal protective equipment. Institute of Business Administration, Tallinn University of Technology, Ehitajate tee 5, EE12618 Tallinn, Estonia

Keputusan Menteri Tenaga Kerja Nomor: KEP-48/MEN/1996. "Baku Tingkat Kebisingan”. Jakarta.

Khajenasiri M., dkk. (2016). The Effect of Exposure to High Noise Levels on the Performance and Rate of Error in Manual Activities. Electronic Physician

Khoiriyah, Dewi. (2009). Aplikasi Analisis Jalur Untuk Motivasi Kerja, Disiplin Kerja dan Linkungan Kerja Terhadap Efektivitas Kerja dan Produktivitas Kerja Di PT Nojorono Kudus. Semarang : Universitas Negeri Semarang.

Madbuli H.N., dkk. (2014). Noise Pollution in Metalwork and Woodwork Industries in the Kingdom of Saudi Arabia. International Journal of Occupational Safety and Ergonomics (JOSE)

Nur, Fitria. (2012). Hubungan Tingkat Kenyamanan Dengan Kelelahan Kerja Pada Pekerja di Bagian Ringframe PT. Kusuma Putra Santosa Karanganyar. Skripsi. Surakarta : Program Diploma IV Kesehatan Dan Keselamatan Kerja, Fakultas Kesehatan, Universitas Sebelas Maret. 
Prabawati, F. (2016). Perbedaan Gangguan Emosional dan Beban Kardiovaskular pada Tenaga Kerja yang Terpapar Kebisingan di Atas dan di Bawah Nilai Ambang Batas di PT. Iskandar Indah Printing Textile. Universitas Sebelas Maret : Surakarta.

Saremi, Mahnaz. (2015). Combined Effects of Noise and Shift Work on Fatigue as a Function of Age. International Journal of Occupational Safety and Ergonomics (JOSE)

Sektiawan D. (2018). The Analysis Of Physical And Mental Work Load Using Niosh Equation And NasaTask Load Index (Tlx) Method. Jurnal REKAVASI, Vol. 6, No. 2, Desember 2018, 60-68 ISSN: $2338-7750$

Suma'mur. (2009). Higiene Perusahaan dan Keselamatan Kerja (Hiperkes). Jakarta: CV Sagung Seto.

Suparni, Sri. (2011). Pengaruh Kebisingan Terhadap Kelelahan Kerja Pada Tenaga Kerja Bagian Instalasi Gizi di Rumah Sakit X. Skripsi. Surakarta : Program Diploma IV Kesehatan Kerja, Fakultas Kedokteran Universitas Sebelas Maret.

Tarwaka. (2008). Keselamatan dan Kesehatan Kerja. Surakarta: HARAPAN PRESS.

Tarwaka. (2011). Ergonomi Industri, Dasar-Dasar Pengetahuan Ergonomi dan Aplikasi Di Tempat Kerja. Surakarta: Harapan Press.

Wahyuning, R. (2013). Pengaruh Kebisingan Terhadap Stress Kerja Pada Pekerja Bagian Weaving di PT. Iskandar Indah Printing Textile. Universitas Sebelas Maret : Surakarta. 